\title{
Isaiah 61:1-3(4-9) 10-11 \\ Transferor of privileges, an "identikit" 1 of the servant of the Lord?
}

\author{
H A J Kruger \\ University of Durban-Westville
}

\begin{abstract}
On the basis of the demarcation of the book of Isaiah into three distinct literary units, scholarly opinion has ruled out the possibility that Isaiah 61:1-4 (5-9) 10-11 (as part of Trito-Isaiah) might be given the status of a so-called Servant Song along with the other group of "genuine” Servant Songs (Isa 42:1-4; 49:1-6; 50:41; 52:13-53:12, as part of Deutero-Isaiah). The paper argues that Isaiah 61 should be integrated with the other four Songs, bringing the number of the Songs of the Servant to five. Arguments to support the case include a profile of the figure in chapter 61 in relation to the one described in the first four Songs; the application of what may be called a "democratization" concept; the mediating function of the figure referred to in Isaiah 61, and the role of the literary structure of the eleven chapters of Isaiah 56-66.
\end{abstract}

\section{INTRODUCTION}

Studies of the book of Isaiah have revealed that different passages in Isaiah 40-66 apparently describe the same anonymous and mysterious figure in a striking manner. This figure is designated as "the servant of the Lord", and the passages comprise Isaiah 42:1-6; 49:1-6; 50:4-9; 52:13-53:12 and possibly 61:1-3 (4-9) 10-11). The number of verses allocated to each passage or "song" may vary according to the opinion of scholars. In the past other passages, namely Isaiah 51:4-6; 62:10-12 (see Brownlee 1964:193-203), and 51:16 (Blocher 1975:21) were also regarded as "servant songs", the latter as a

\footnotetext{
${ }^{1}$ In this paper the term "identikit” takes on the meaning of "a composite sketch".
} 
fragment of a servant passage. The intention of the present study is to explore the possibility of a closer connection between the first four servant passages and Isaiah 61, which is here espoused as a fifth servant song.

The interpretation of these passages is hampered by a number of problems, which have been debated over the years. Not all the relevant issues relating to the passages and the figure concerned will be addressed in this paper. Consequently some will be addressed briefly, others confined to footnotes, and others laid to rest. Questions were raised regarding the delimitation and interpretation of the relevant passages against the background of the demarcation of the book of Isaiah as a whole. Related to the latter is the question of whether these passages constitute a separate literary group or not ${ }^{2}$. Be that as it may, the most important issue for the present study revolves around the status and function of the figure in Isaiah 61:1-3 (4-9) 10-11. Questions dealing with the latter include whether this figure should be understood as a collective or an individual personality, the related problem of the figure's historical identity, the nature of his office $^{3}$, as well as possible messianic features ${ }^{4}$ conferred upon him.

\section{THE DIVISION OF THE BOOK OF ISAIAH, AND SOME CONSEQUENCES}

Scholars reacted differently to the demarcation of the book generally ${ }^{5}$, and the delimitation of the passages concerned in particular (Childs 2001:323). As a result of the division of Isaiah into three parts (Isa 1-39; 40-55; 56-66), scholarly opinion in the first place ruled out the possibility that Isaiah 61:1-3 (4-9) 10-11 might be given the status of a

2 E g North (1956); De Leeuw (1956); Grosheide (Old Testament 1978a; New Testament [1978b]); Beuken (1989a; 1989b:411-442); Childs (2001:503); Koole (1995:259, 261, 263, 283); Smith (1995:2225); Watts (1987:116).

3 See Dion (1988:319-339), De Leeuw (1956:298, et passim); North (1956:139, et passim); Blocher (1975:72); Soggin (1975:913); Thomson (1955:406-418); Dijkstra (1978:44).

4 See Soggin (1975:914); Motyer (1980:987-993); Fiedler (1997:119-129); Johnson (1993:107-136); Bratcher (1984:65-71); cf Childs (2001:422-423); Du Plessis (1995:12-14; 146-152); Goulder (2000:6674).

${ }^{5}$ Harrison (1977:764-800); Dillard \& Longman (1994:267-283); Beuken (1989a:8-10); Alter \& Kermode (1989:24-25, 165); Prinsloo (1999:770-771); Erlandsson (1970:64-65, 102-1-5, 164-166); Gileadi (1994: 147-151, 162-164); Mitchell (1999:25); Schökel (1989:165, 177); Prinsloo (1999:770); Childs (1979:27106; 311-338); contra Gileadi (1994:2-43). 
so-called "servant song" along with the other group of "genuine" servant songs, the latter of which are restricted to Deutero-Isaiah. A second group defended Isaiah 61 (or part thereof) as a genuine servant of the Lord passage. A third group noted similarities between the first four passages and Isaiah 61, without concluding that the latter passage deals with the servant. Those who espouse the latter position, understand Isaiah 61 as a first interpretation of the four servant songs of Isaiah 40-55 (cf De Leeuw 1956:5; Beuken 1989b:411). According to Childs (2001:502-503) the most representative opinion in this regard is probably the view that Isaiah 61 deals with the calling of TritoIsaiah who identified himself with Deutero-Isaiah. However, he is cautious not to understand the passage as the calling of Trito-Isaiah or to associate the figure of Isaiah 61 with the servant of Isaiah 40-55 prematurely. According to Koole (1995:261, 263) the figure of Isaiah 61 resembles the servant. Thus, generally speaking it appears that the viewpoints relating to the question of whether Isaiah 61 deals with the servant remained the same over the last decades, with a few new nuances here and there. ${ }^{6}$

Be that as it may, from a survey of the current state of studies on the prophets (Gordon 1995:3-605), it is clear that the figure of the "servant(s)" in the book of Isaiah still attracts attention (Blenkinsopp 1995:392-412). However, it is also clear that the main argument which prevented Isaiah 61:1-3 (4-9) 10-11 from taking its place among the genuine songs of the servant was based on the separation of Isaiah 40-55 from chapters 56-66 (Kruger 1984:37). It is somehow ironic that scholars persist in maintaining such a sharp division between the first four songs of the servant and Isaiah 61 . This view prevails in spite of the fact that the passage concerned represents the nearest equivalent of the first four servant passages in form and content than any other passage in Isaiah or in the Hebrew Scriptures as a whole for that matter.

\section{THIRD ISAIAH, ISAIAH 61, AND SERVANT(S)}

Over the last few years studies on the subject of the songs of the servant tended to move sideward. This means that investigations presently deal with aspects of individual servant passages only (cf Van Ruiten \& Vervenne 1997). Thus, generally speaking,

${ }^{6}$ Cf Kruger (1984:38) for viewpoints of researchers of the past and more recently Ekblad (1999:17-290); Childs (2001:502-503). 
current studies do not consider all the songs together and/or the possibility that the servant of the Lord takes the floor in Isaiah 61 in a way akin to the first four songs, thus integrating (at least part of) the latter chapter with the first four passages. The nearest that scholars come to considering this option, may be seen from investigations which concentrate on the "servants" referred to by Trito-Isaiah, that is Isaiah 65:8-15 and 66:14 (Beuken 1989a:15-17; Blenkinsopp 1995:392-412). However, to limit a study of the "servants" to Trito-Isaiah is undermined by the observation that references to individuals indicated as such already appear in Proto- (cf 20:3) and Deutero-Isaiah (cf Isa 54:17). Be that as it may, authors still refrain from identifying the figure of Isaiah 61 explicitly with the servant proper in the same manner as in the first four passages (Childs 2001:503; Koole 1995:259, 261, 263, 283; Smith 1995:22-25). In some cases where Isaiah 61 is discussed, the problems concerned seem to be passed over in silence (Brueggemann 1998:212-215).

In order to address the status and function of the figure of Isaiah 61, a preliminary question must be dealt with first. Does Isaiah 61 qualify as a servant of the Lord song? Put differently: Is it possible to view the figure of Isaiah 61 as the servant of the Lord? Closely related to the latter is the question of whether the figure should be understood as a collective personality or an individual.

\section{THE RELATIONSHIP BETWEEN DEUTERO-ISAIAH AND ISAIAH 61: THE STATUS OF THE FIGURE CONCERNED}

To gain a better understanding of the problem the exegete will do well to move back one step, and consider the relationship between the figure of Isaiah 61 and the preceding Isaiah 40-55. In this connection Beuken (1989b:414-438) has undertaken an investigation of all the texts in Isaiah 61, which allude or refer to Isaiah 40-55. This situation, however, does not move Beuken (1989b:415, 424, 429-430, 438) to identify the speaker of Isaiah 61 as the servant of the Lord. Author of this article on the other hand is convinced that the survey confirms that Isaiah 40-55 created the framework and prepared the space for the action of the figure of Isaiah 61, which proved to be the servant of the Lord. The conclusion of Beuken (1989b:413, 415, 424, 429, 432, 438) regarding the figure of Isaiah 61 remains ambivalent. He uses the word "prophet" in his discussion of 
the figure concerned, but leans toward the servant figure when he discusses the content of the chapter. He halts between two opinions since he states that when speaking about the prophet with reference to Isaiah 61, it does not mean that he does not have the servant in mind (!) His objection against the designation of the speaker of Isaiah 61 as the servant of the Lord, links up with exegetes of the past, namely that essential elements characterising the servant are lacking in Isaiah 61 . He mentions the pronouncements of the Lord that he chose this individual and refers to Isaiah 42:1-6 and 49:1-6. According to him the latter refers to the servant's trust/faith in the Lord, and his justification in Isaiah 49:1-6 and 50:4-9; 53. It should be clear, however, that precisely those characteristics mentioned by Beuken, appear only in some of the accepted genuine songs $^{7}$. Again: What is the basis for the requirement laid down by scholars that a selected number of features must consistently appear in all passages investigated before such a passage may qualify as a song of the servant? Apparently the real reason why Isaiah 61 does not qualify as a song of the servant, is not about the lack of requirements, which are based exclusively on the first four songs, but the consistent application of scholars' opinion that Isaiah 56-66 must be severed from chapters 40-55.

\section{THE FUNCTION OF THE FIGURE DESCRIBED IN ISA 61:1-3 (4-9) 10-11}

The main issue thus boils down to whether the portrayal of the servant of the Lord as presented by Deutero-Isaiah continues in Isaiah 61. An important aspect which supports the development of a particular "identikit" for the figure of Isaiah 61 is provided by the principle of "rolling down", that is, passing on or carrying over the "status" acquired by one person onto certain beneficiaries. To explain this idea, it is necessary to use certain devices to illuminate the function of the figure described in Isaiah 61. The way to approach the problem is to look at the "roots" of the figure(s) concerned. In this connection and regarding the content of the book, it needs to be noted that it is characterised by eschatological features throughout (Gileadi 1994:29). More than thirty

\footnotetext{
7 There are also other reasons why Isaiah 61 may be classified as a servant song, in the same way as the first four; see Schökel (1989:166); Delitzsch (1889:395-396); Cannon (1929:284-288); contra North (1956:138).
} 
important historical antecedents (implicit and explicit) relating to ancient Israel are used in Isaiah to typify eschatological moments. The passages dealing with the servant of the Lord operate within this perspective or sphere ${ }^{8}$. In this respect the discussion of Avraham Gileadi may guide the reader (Gileadi 1994:87-213; 1982:171-207; cf Brownlee 1964:247-259).

\section{ASSUMING AND TRANSFERRING TYPOLOGIES}

According to Gileadi (1994:112-118) a pattern ${ }^{9}$ can be discerned in Deutero-Isaiah whereby certain typologies are assumed by biblical and non-biblical figures on the one hand (e g 44:28; 45:1), and others transferred from them to still other figures on the other. Important for the present study is the fact that Cyrus' status as the Lord's anointed (45:1) possesses parallels elsewhere, as in the anointed status of the composite figure in Isaiah 61:1. Among the many rhetorical links between the various Isaianic figures, this motif of anointing illustrates the close typological relationship between two of them in particular, namely the Cyrus and servant figure. In Hebrew tradition, the anointing of a king or vassal and his endowment with the Lord's Spirit occurs as two complementary phenomena (cf 1 Sam 10:1, 6-11; 16:13). What the Lord confers upon one figure, however, manifests itself in the other: Cyrus features as the Lord's anointed (45:1), but the servant figure exhibits an endowment of the Lord's Spirit (42:1). These ideas come together in the figure in Isaiah 61 as a cumulative concept: "The Spirit of my lord the

8 This applies to the difference between the "former things" and the "coming/new things", the new creation, the new exodus, the references to the Lord as the Holy One of Israel, the King, Judge, Saviour/Messiah and Creator (Gileadi 1994:28, et passim).

9 Also important for the present study is the recent observation that the book is dominated by certain literary structures and not only by historical markers. These structures dominate the whole book but each in its own way. It would appear that this possibility has been overlooked or underestimated by traditionhistorical and form-critical approaches (cf Childs 1979:311-338). Studies have shown that certain literary patterns and structures found in the book have been taken over from the literature of the ancient Near East (Gileadi 1982:173, footnote 3). On this basis and following the suggestion of Brownlee (1964:247-259), Gileadi (1982:172-206) has shown that the whole book of Isaiah is dominated by some of these literary patterns and others. This approach put new challenges to any attempted analyses of the book, and confirms its unity at the same time, albeit in an indirect way. Consequently, some authors are moving away from a strict historical approach of the book and take as point of departure a literary vision without repeating and evaluating all the relevant problems raised in the past (Alter \& Kermode 1989:166-183; Hill \& Walton 1991:319-326; Ryken \& Longman 1993:310-323; Smith 1995; Oswalt 1998). 
Lord is upon me, for the Lord has anointed me.” The latter observation touches the right chord and underpins the argument put forward in this article.

However, examples of typologies transferred from Cyrus to others, again besides those already mentioned, include the restoration of Jerusalem and the land's ruins. The restoration of the land's ruins, for which Cyrus sets a precedent (44:26, 28), is also undertaken by those whom righteousness leads in a new exodus in Isaiah 58:8, 12 . According to Isaiah 61:1-4 the restoration of ruins is undertaken by the "anointed" one and certain mourners in Zion. The Lord's elevation of the Cyrus figure to royal office "in righteousness" (בצדק, 45:13) ${ }^{10}$ also applies to the servant figure (42:6) and, in a variant form, to Jacob/Israel (41:9-10). The term righteousness thus expresses that aspect of royalty, which meets divine approval, the ideal king, or a legitimate vassal being justified (צדק) (see further Gileadi 1994:87-213). It may prove helpful to summarise and consider the findings of Gileadi (1994:125) together:

\section{Typologies of the Lord's ideal agent of punishment and deliverance: a diagrammatic summary}

Gileadi's explanation of the first part of Isaiah may be presented in diagram form.

The following types of the ideal Davidic king may be grouped together:

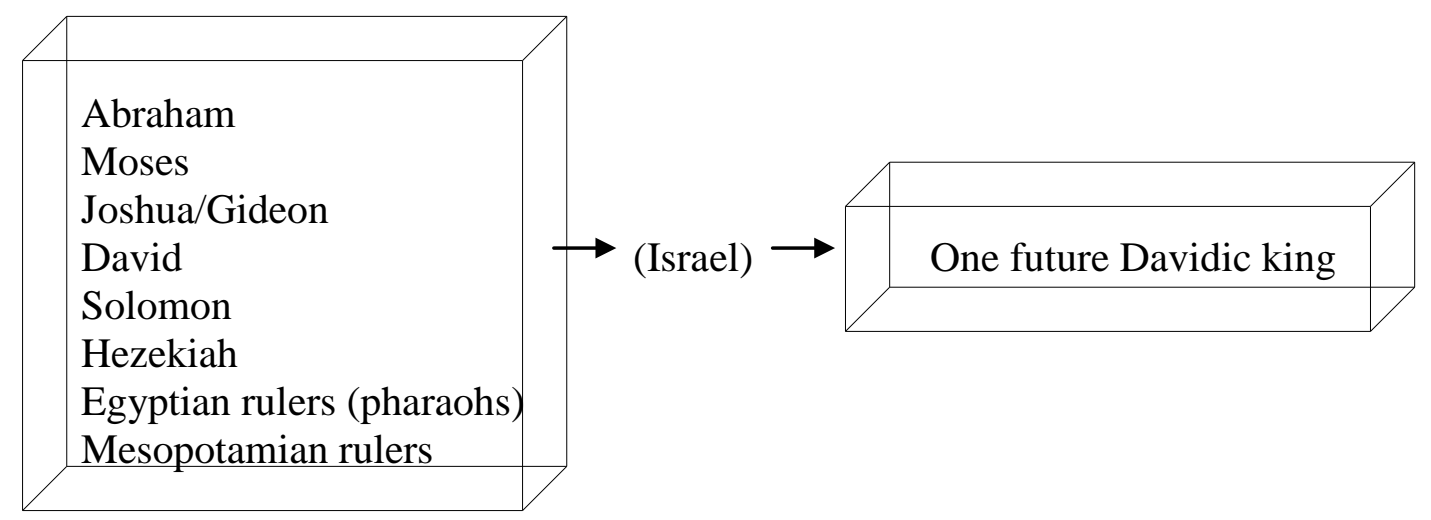

Again, in a general way, moving toward the last major part of the book, and which is of greater importance for the present discussion, types of the servant of the Lord may be classified as follows:

${ }^{10}$ A Mesopotamian legitimation formula, see Paul (1968). 


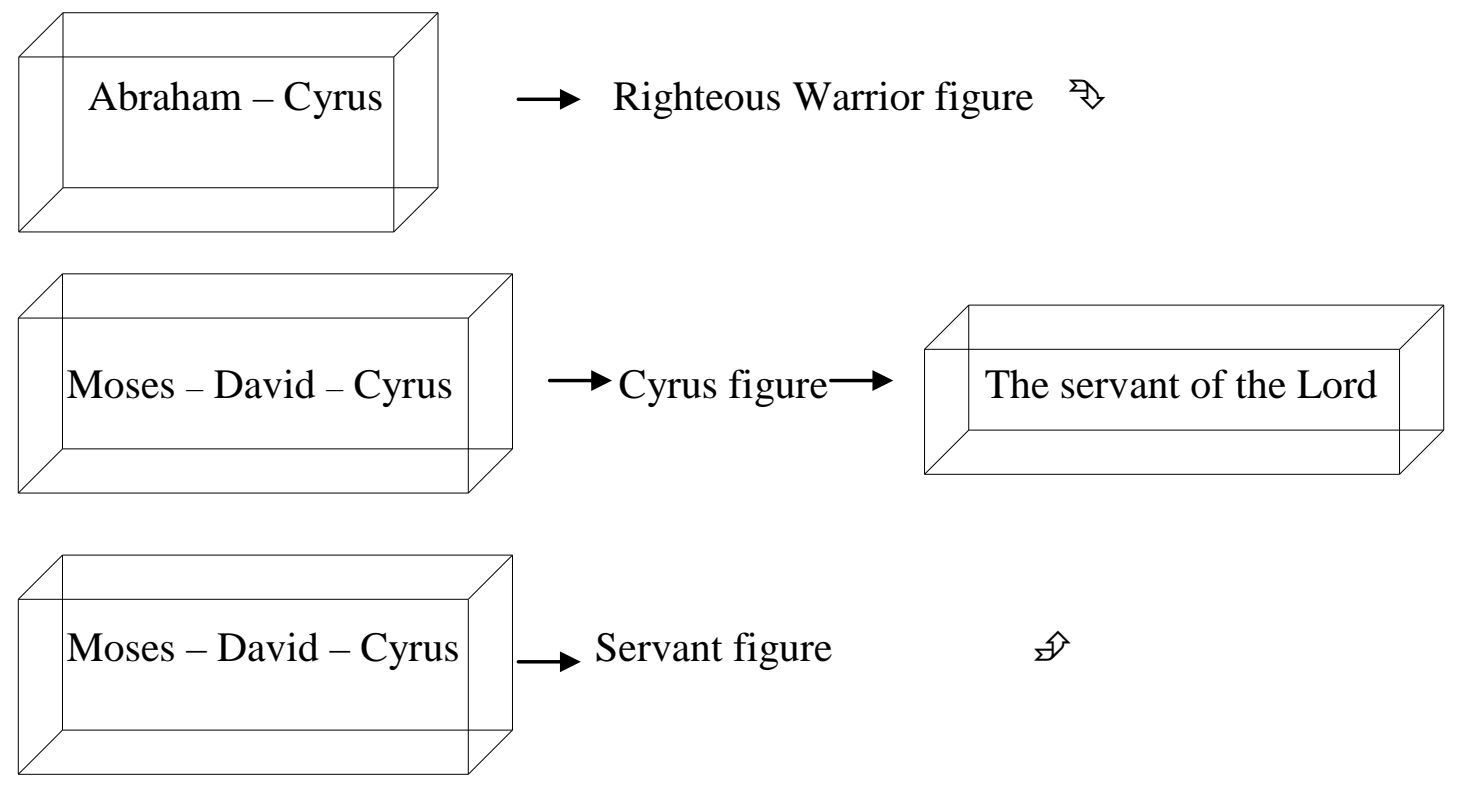

In turn these typologies are underscored by metaphorical pseudonyms. The pseudonyms sometimes overlap with, or replace the typologies:

\section{Metaphorical pseudonyms}

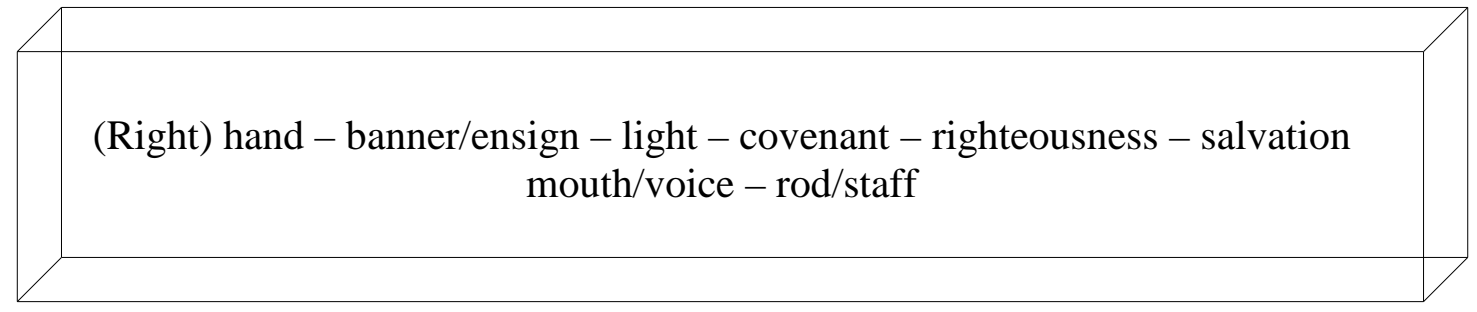

Only Abraham and Cyrus typologies constitute the righteous warrior figure. The MosesDavid-Cyrus types are building blocks for Cyrus and the servant. Finally, the righteous warrior and Moses, David, and Cyrus converge in the (one) servant figure.

Thus there seems to be a progression of thought from an initial dealing with a number of figures presented earlier in the book to a later (or final) stage where the texts focus on a single or composite figure regarding the redemptive work of the Lord. Sometimes these figures also overlap, in other cases they find expression under pseudonyms. Of great significance for the present study is the observation made above that these figures assume and shed part of their features on occasion. In some cases certain characteristics are taken over by a figure and in other cases other figures transfer 
certain capabilities to other individuals (Gileadi 1994:117-118). It is thus not unusual that the figure of Isaiah $61: 1-3(4-9 ; 10-11)$ also acts within this framework.

It gradually becomes clear from Isaiah 1-39 that as a result of the task given by God to ancient Israel to act as servant of the world, the latter found it increasingly difficult to execute. This led to suffering and failure (Watts 1985:xxiv-xxv). Consequently the task is transferred to the servant, who goes under as a result of the burden as portrayed in Isaiah 52:13-53:12 ${ }^{11}$. However, the result or outcome of the servant's work, namely bearing the sins of many, and bringing about redemption, is transferred to his offspring. The point of departure for this stance is the fact that the seed (זרע) of the servant will act $(54: 2,3)$, whether understood as inheriting from, or dispossessing of the nations (Koole 1990:284-285; Beuken 1983:248-249).

\section{ISA 61, BIBLICAL HEROES AND RELIGIOUS CUSTOMS AND ACTS}

Against this background the impact of the actions, and the association with certain religious customs of historical figures on the creation of a unique identity for the figure of Isaiah 61, must be considered. Certain texts in Isaiah 61 allude to ancient Israelite leaders, customs or actions. However, the individuals originally associated with the customs or actions are not mentioned by name. Thus, in Isaiah 61 those actions are dissociated or detached from their "original owners" and in stead attached to the personality portrayed in Isaiah 61.

A first case in point is the patriarch Abraham. His name is linked to God's eternal covenant (Gen 17:7, 13, 19), which in turn in Isaiah 55:3 is connected to the kingship of David (2 Sam 7:12-13, 16; 23:5; cf Isa 61:8). Moses also seems to have earned a part in the compilation of the figure of the servant. Against the background of the exodus his name is associated with proclaiming the duty of redemption (Lev 25:1, 9-10; Isa 61:2; 63:11ff), as well as the statement that the firstborns will receive a double portion (Deut $4: 44 ; 5: 1 ; 10: 1 ; 10 f f ; 21: 15-17)$. Regarding the exodus and the release from exile, the offices of Moses and Cyrus the Persian king overlap. Cyrus freed the exiles and restored

${ }^{11}$ Compare Gileadi (1994:190-212) and Wiesel (1970:56-57). 
Jerusalem (44:28; 45:13; cf 61:1, 4). The action of Joshua possibly supplied another building block for completing the portrait of the servant figure. His name is linked to the division of the land (Num 26:52ff; Josh 11:23, cf Isa 61:7). Aaron was responsible for the priesthood and his office probably lingers in the background (Lev 8:1ff; Ex 19:5-6; cf Isa 61:6). The conclusion reached here is that the servant's actions are presented in Isaiah 61 as a composite portrayal based on religious acts and customs linked to individuals from Israel's past. It seems clear that all the figures as pointed out by Gileadi not only determine the identity of the servant of Deutero-Isaiah, but also the figure of Isaiah 61, except for Aaron who plays a role in the latter passage. However, it seems possible to argue for a dominating Davidic gene in this figure ${ }^{12}$.

\section{DAVID AS DOMINATING GENE OF THE FIGURE IN ISA 61}

In Isaiah 37:35 king David is designated as God's "servant" par excellence (cf Ezek 34:23-24; 37:24; Jer 33:21, 36) (cf Kruger 1984:43-44). This may reinforce the possibility of identifying the figure of Isaiah 61 as the servant of the Lord. The reason for this statement comes from the following observation. Two motifs go hand in hand in the so-called royal psalms (portraying the Davidic king) and Zion psalms (the focus on Zion). This double motif (the combination of the royal and Zion motifs) continues in Isaiah (Isa 37:35; 38:6 - Gileadi 1988:157-163). For the present purpose it needs only to be noted that since the Zion motif flanks Isaiah 61 on both sides (chapters 60 and 62), it follows that Isaiah 61 must be dealing with the Davidic king. In the light of the close association between Zion and David as servant (Isa 37:35; 38:6) it seems possible that the figure of Isaiah 61 is the servant of the Lord (cf below under literary structure). As an aside it may be mentioned that David is the only king associated explicitly with consoling someone else (61:2 - see elsewhere in this paper). The joy expressed by the figure under discussion (61:10), reminds of David's own experience in this regard (Ps 30:12).

\footnotetext{
${ }^{12}$ In their attempts to identify the figure of Isaiah 61, some authors have moved away from a personal to an impersonal dimension. In this respect some see a connection between the figure of the servant and a city, a servant city, "Zion-Jerusalem" (Wilshire 1975:356-367; Sawyer 1989:89-107). However, the same tendency also relates to Babylon (13:1). All "non-Zion" entities are incorporated under a single Babylon "umbrella" (cf 43:13ff, Gileadi 1994:144-151). The city element should be distinguished from the personal.
} 


\section{ROLLING DOWN TYPOLOGIES AND PRIVILEGES ONTO BENEFICIARIES}

Returning to the main thesis of the paper it seems clear that a form of "democratisation"13 determines the status and function of the figure of Isaiah 61. This interpretative key enhances the link between Isaiah 61 and the first four servant songs. The concept also creates a framework or role for the figure of Isaiah 61 to mediate the achievements of the servant for the benefit of and to be transferred to the servants referred to in Trito-Isaiah (cf 54:17). Again: The idea of the incorporating personality relates to the rolling down of the results of performance by the performer, or transferor onto certain beneficiaries. The idea of transferring benefits (or virtues for that matter) provides a useful interpretative key whereby Isaiah 61 may be understood as referring to the servant of the Lord. This function or principle of transferring virtues gained or achievement of certain qualifications serves a meaningful purpose only in the context of the whole book of Isaiah.

This idea and reasoning must be highlighted further. Not only are typologies transposed or exchanged between the figures as indicated above, but typologies and what goes with them, are also transferred from the servant of the Lord to his servants in TritoIsaiah. The basis of the present argument relates to the result of the work of the servant, which in chapter 56-66 is transferred to his servants (Isa 65:8-15; 66:14; cf Isa 20:3; 54:17). The role of the servant of the Lord in Trito-Isaiah thus incorporates or embraces that of mediator, of transferor, or distributor of the benefits of redemption to his servants. The following discussion will hopefully help to explain this principle.

The reader learns that the laboured suffering of the servant $(42: 4 ; 49: 4,7 ; 50: 5,6$; 53:11) will result in his seeing his offspring ( $r z ; 53: 10 ; 65: 9)$ (Kaiser 1979:215-217). This outcome or fruit and making available of the work of the servant to his servants continue in Isaiah 56-66. By his knowledge the righteous servant shall vindicate many (53:11, צדיק צדיק"; cf 60:17). It is necessary to dwell for the moment on this one particular aspect, namely the trait of "righteousness" (צדק). One manifestation of the ideal agent of the Lord's redemption is the figure of the righteous warrior. Isaiah 41:2

\footnotetext{
13 In this paper the word "democratisation" is separated from its usual political context, and used in the sense of carrying over or making available the benefits earned by one person to other persons.
} 
(vv 1-3) depicts a person called "righteousness" (צדק). Gileadi (1994:106, footnote 34) understands the word as a personification (53:11; 62:11). This personification is borne out by being associated with Abraham and Jacob/Israel, and Cyrus $(41: 2,8)$ who acts or experiences the same as the former (Gen 15:6; 12:1; 41:9, 15; also comp. Gen 12:8; 14:13-15 with Isa 41:25). The same applies to the metaphor of the Lord's right hand (41:13-15). Jacob/Israel lacked the two attributes of righteousness (and calling on the Lord) when the ideal figure fulfilled his mission (43:22; 46:12). However, some of the Lord's people did acquire these attributes as a result of that mission (51:1, 7; 58:8-9) (Gileadi 1994:126, footnote 72). Thus, the righteous figure of Isaiah 53: 11c brings about righteousness in other persons (53:11d) ${ }^{14}$. This phenomenon forms a basic tenet of the work of the figure of Isaiah 61, and portrays him as the servant of the Lord. On this basis the faithful are summoned to follow suit (56:1).

The word דכא gives special meaning to the relationship between the servant and his servants. It was the will of the Lord to oppress his servant (דכאיץ - 53:10), for the sins of mankind (מדכא מעונתינו - 53:5). In future the Lord will dwell with those who are broken (דכא - 57:15), namely with his people who were crushed in the past (תדכאו 3:15). The Egyptians who were cast down will also share in God's presence (מדכאים 19:10). The servant was struck down by disease and misery, enduring suffering and pain, because he was burdened with the infirmities of others $(53: 3,4)$. As a result he is capable of binding up the broken-hearted (לחבש לנישברי-לב, 61:1, cf 57:18). In contrast, the unfaithful will cry from an aching heart (65:14). The servant (עָבד 52:13-53:12) announces the outcome of his achievement (61:1ff) and transfers this epithet onto his servants (עבדיi respectively עבדיו, cf 42:1 and 65: 9, 13, 15). As the chosen of the Lord (בחירי, singular 42:1), he creates this privilege for others, now called "my chosen ones" (בחירי), plural 65:9, 15, 22). In this connection the summons rings out to prepare the way

${ }^{14}$ There are several textual references where believers are indicated as being righteous (Gen 7:1, et passim, cf Lisowski 1958:1205-1209). However, in context these indexes probably relate not so much to a new inherent nature achieved or gained, but as a basis for supplication (the Psalms), or a wise attitude of life (Job and Proverbs). Ecclesiastes cautions against an unfounded righteous air in men (7:16); that there is in fact no righteous person on earth (7:20), and that should there be any possibility in this regard, this rests in the hand of God (9:1). This being the case, Isaiah 24:16a refers to praises being offered to a so-called righteous nation - however, the prophet opposes this and in stead characterises this nation as depraved (24:16b). No god (or messenger) deserves to be designated as "right” (41:26); only God's servant passes this test (42:1). On this basis the servant can declare others as righteous (53:11; 60:21). 
for God's people (ם[h פנו ררך, 62:10). Previously this was applied to the Lord himself (hwhy פנו ררן, 40:3). The everlasting covenant which the Lord had made with David (2 Sam 7; Ps 89) now applies to his servants (55:3: אכרתה לכמ ברית עולם; 61:8: (ברית קולם אכרות לכם). The kingship, which belongs to the servant by virtue of his anointing $(42: 1 ; 61: 1)$ is transferred to the priests, that is, according to Exodus 19:5-6, the kingdom of priests (61:6). Also the royal symbol of the crown (עטרת) is handed over to the servants. According to Isaiah 28:5 the Lord represents the crown of his people; in Isaiah 62:3 the reader learns that the people of God is the crown of the Lord. This image contrasts with the one where the crown of the arrogant drunkards of Ephraim will be trampled under foot $(28: 1,3)$. The comprehensiveness of the transference of these achievements of the servant to his servants also applies to the fact that the holiness of the Lord (קדוש יהוה, 62:12; [, 63:18). A concept closely related to holiness, namely the power (glory) of the Lord (60:1ff, כבוד יהוה) also characterises Zion (כבודך, 62:2). As an aside it may be mentioned that the infinitives describing the task of the servant in Isaiah 61:1-3, relate to the sevenfold virtues of the (messianic) figure of Isaiah 11:2 (cf Koole 1995:264). The latter support the idea of the servant making available his virtues to the faithful.

\section{TYPOLOGIES ASSUMED AND TRANSFERRED: THE ROLE OF THE COVENANT CONCEPT}

The whole enterprise of transposing typologies, and for the present purpose, especially the outcome of the work of the servant, carried over from and by the Lord's agent to others, finds a good basis in the phrase "as a covenant of or for the people" לברית עם), parallelled by the words, "a light for the nations" (לאור גוים, 42:6b). The pledge of everything said so far in connection with the principle of rolling down virtues won, reside in the fact that the servant acts as the covenant mediator for Israel (לאור גוים) ואצרך ואתנך לברית עם, Isa 42:6). God made his covenant with his people through the covenant mediator (55:3) and transfers the benefits of the covenant to them through the same person (61:8, cf 59:21). The Spirit resting on the servant represents the testimony and evidence that the covenant has indeed been made with God's people (59:21). Isaiah 
61:1-11 testifies to the good tidings of the outcome of the work of the servant. This reality provides the basis of all the data, which confirm that Isaiah 61 belongs to the first four songs of the servant. Without Isaiah 61 the other songs of the servant remain a torso. The first four songs of the servant deal with the achievement of the servant. Chapter 61 spells out the fruit, the handing down of this achievement. A complete picture ("identikit") of the servant emerges only when the five songs are interpreted together.

This view is further supported by the following argument. The figure of Isaiah 61 occupies a most significant place in the mind of the author. This observation can be gleaned from the literary structure of Trito-Isaiah.

\section{THE LITERARY STRUCTURE OF ISA 56-66}

The eleven chapters of Isaiah 56-66 apparently display a symmetric pattern, which consists of a conical (pyramidal) literary structure or "shape". The apex of this structure is capped by chapter 61 , which thus represents the centre of these chapters. This passage is flanked on both sides by parallel passages, which reveal some striking resemblances. Different attempts have been launched to indicate how this structure is set out, since it seems obvious that some pattern emerges from behind the words ${ }^{15}$. The suggestion proposed here:

15 For other attempts, compare e g Westermann (1967:154); Kidner (1970:620); Motyer (1993:461). However, this structure does not exclude a linear reading of the texts (Beuken 1989a:15). 


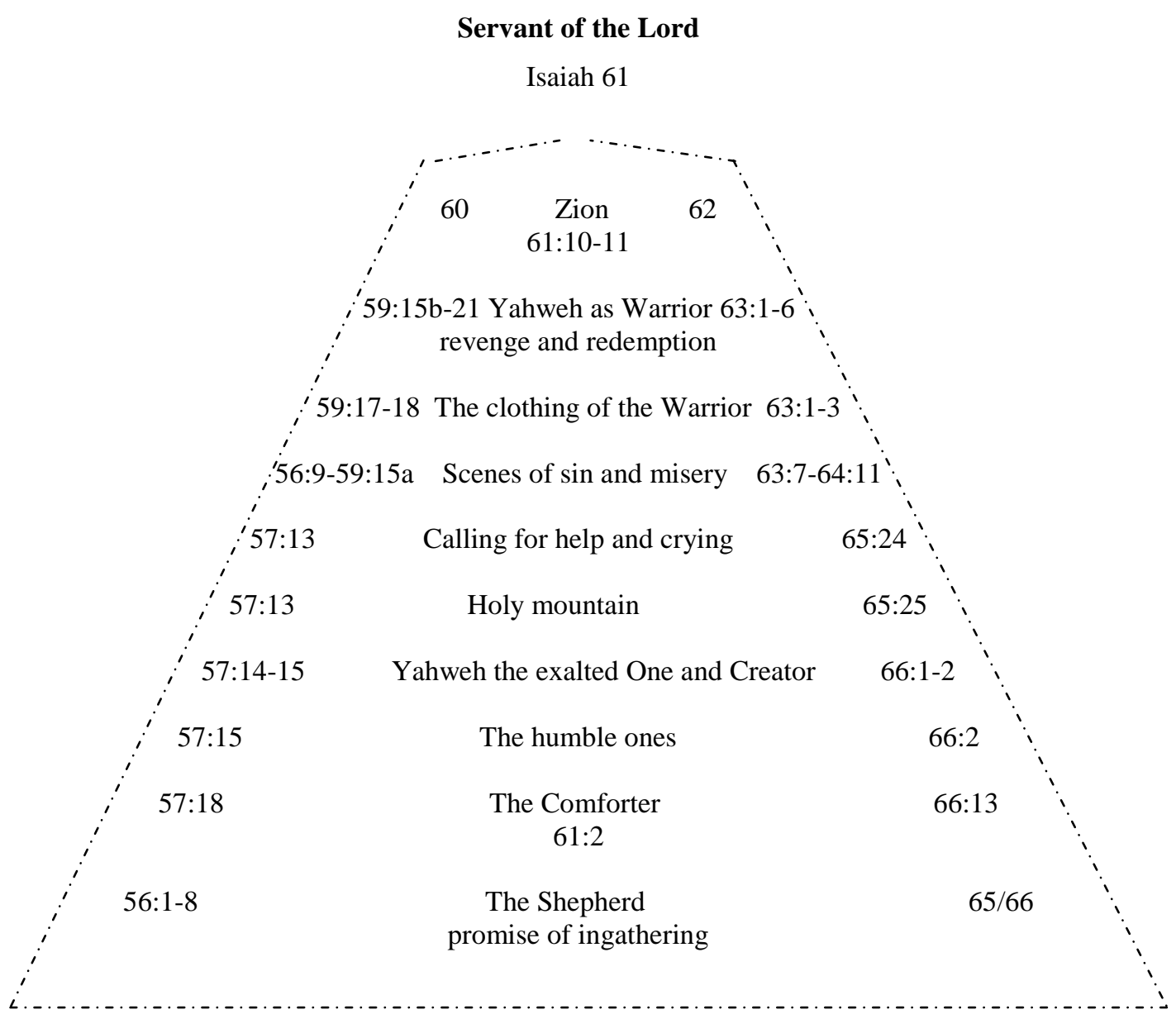

From the analysis it seems clear that the whole of Isaiah 56-66 revolves around chapter 61 where the figure under discussion is prominently positioned, and flanked on both sides by the exaltation of Zion (Isa 60 and 62). The passages dealing with the warrior frame the latter since the rest of Zion is guaranteed and preceded by the victory of the Lord as warrior over his enemies. As a result, and as shepherd he gathers his flock worldwide (56:1-8; 65:1-66:24) and comforts them (57:18; 66:13). The latter task is shared by the Lord and the figure of Isaiah 61:2. As king (57:14ff; 66:1-2), and creator (57:15; 66:2) the Lord controls everything in the universe. It seems clear that the function of this conical structure serves a theological and not a historical aim.

The prominent position given to chapter 61 in the overall structure of Trito-Isaiah, which deals mainly with the figure under discussion, proves his importance. This underscores the possibility that this figure is the servant of the Lord as described in the first four servant songs. 


\section{THE FIGURE OF ISAIAH 61: COLLECTIVE OR SINGLE?}

This problem also relates to the status of the figure of Isaiah 61. During all the main periods of the history of the interpretation of the servant passages, this figure was taken as representing either a collective or individual personality (cf De Leeuw 1956; North 1956; see Watts 1987:127).

The collective approach usually associates the servant with the "historical" Israel, the "ideal" Israel or a "core" in Israel (see Kruger 1984:43). This viewpoint has substance. And there is no need for any academic resistance against it, since some texts in Isaiah do have that meaning (Watts 1985:117). The "servants" referred to in Isaiah 65:8-15 and 66:14, could have initiated the collective interpretation of the servant in Isaiah 40-55. Recently this approach received fresh impetus with the view of Blenkinsopp (1995:392-412) who argued that the "servants of the Lord" in Trito-Isaiah represent a pietistic group in the Persian period. Van der Kooij (1997:383-396) thinks along the same lines when he identifies the servants of the Lord with a Jewish group in Egypt. One problem with the collective view is the issue of whether ancient Israel was capable of bearing the sins of others (Isa 52/53).

The alternative view, namely understanding the servant as an individual, yielded different possibilities. The servant may represent a historical person ( $\mathrm{cf}$ above). Personalities that come to mind, are the patriarchs Abraham, Jacob (or one on his sons), or Job. Other considered the figure of Moses ${ }^{16}$, Isaiah, Jeremia, or a teacher of the Law as an individual servant. From the ranks of the kings and other leaders who were considered as possible candidates, the names of Gideon, David, Hezekiah, Uzziah, Josiah, Joiachin, Zerubbabel, and Meshullam were mentioned. Non-Israelite rulers who were considered, include the Egyptian pharaohs, Mesopotamian rulers, or Cyrus, the Persian king (see Kruger 1984:43) ${ }^{17}$. An attempt was also launched to create a link between the identity of the servant of the Lord and a female servant figure (Korpel 1996:153-157.).

\footnotetext{
16 The most recent attempt to identify the figure of the servant with Moses comes from Baltzer (2001:2022).

${ }^{17}$ See Kruger (1993:66-88) and Curtis (1996:31).
} 
It seems fair to say that in Isaiah the servant is presented in a collective and an individual manner. Again: Israel represents the servant of Lord, subject to the reservation that this only applies to a certain extent. Besides that it must be kept in mind that a certain development of thought regarding the figure concerned takes place as the prophecies in the book unfold. On this basis arguments can be put forward to substantiate the view that the choice for an individual figure also stands on firm ground. On the one hand such an individual can function as a certain extension of Israel (continuity), but on the other, the figure may be distinguished from Israel as well (discontinuity), as was indicated in part above. The statement in Isaiah 49:5-6: "The Lord had formed me... to be his servant, to bring Jacob back to him... It is too slight a task for you, as my servant, to restore the tribe of Jacob, to bring back the survivors of Israel”, forces the exegete to consider a distinction between two facets of the figure or two different personalities. The collective terms in the description of the servant included the whole of Israel, but constantly focused on one representative who carried the destiny of the whole. This connection can be found in the everlasting covenant between God and the Davidic king (expressed in Isaiah as die "seed” or "sprout”; see Odendaal 1970:128136). The tension between the collective and individual dimensions of the servant of the Lord is removed when it is remembered that in the ancient Near East the king represented his people, that the king may act as his people (Kapelrud 1971:311-313).

It would appear that the book of Isaiah presents the servant of the Lord in three ways. Thus, the figure may be viewed in collective and individual terms, or, taking a middle position, the "servant" in Deutero-Isaiah appears as ambiguous, and thus allows for a certain reciprocity of meaning between an individual and a collective sense. This composite nature $^{18}$ (“double” personality, cf for a discussion, Kruger 1984:44) of the servant of the Lord is preceded by and especially based on a series of historical personalities taken from biblical narratives to create the one servant figure (see above). However, also in this respect the covenant concept may solve the problem.

${ }^{18}$ The portrayal of a composite figure in Isaiah or the Old Testament is not unusual. Samuel and Saul were also viewed as such (Rogerson 1999:64, 70). 


\section{COLLECTIVE AND/OR INDIVIDUAL SERVANT: THE ROLE OF THE COVENANT CONCEPT}

During the monarchial period, the Lord made separate covenants with both the kings and the people of Israel/Judah (2 Sam 7:13-14, 23:5b; Ps 89). In this way both the Davidic king and his people had a covenantal relationship with God. Thus, the covenant contained a double focal point. This double focal point also crops up in Isaiah and is associated with both Israel and the servant of the Lord. The texts distinguish between the "servant of the Lord" and the "servant Israel”, by way of speaking, as both figures are associated with a covenant relationship with God. Thus, the same covenant relationship, as it operated before and during the monarchial period, is maintained in Isaiah. This also explains the many similarities and overlapping of references between the two "personalities" of the servant of the Lord and the servant Israel.

This reality however does not mean that the exegete is forced to conclude to a complete identity between the two figures. This is borne out by the fact that the servant of the Lord acts as representative for the servant Israel (אצרך ואתנך לברית עם לאור גוים, Jes 42:6; cf 49:5-6). A striking phenomenon in the servant of the Lord passages relates to the oscillating between the servant as subject (Isa 49:3) and the servant as object in connection with the work of the servant (49:5c-6) (cf Kaiser 1979:215-217). This reality crops up within the framework of one passage. On the basis of his covenant (49:6a), the Lord appoints his servant as the covenant with, or for his people. The servant of the Lord incorporates the covenant between God and his people. The servant of the Lord is thus distinguished from the people of God, the servant Israel. These pronouncements are informed by the so-called incorporating personality (corporate personality)(Gileadi 1994:105, footnote 39, et passim).

Conclusion: The passage of Isaiah 61 whether in full or in part merits the status of a servant song. The main argument used to promote this view is based on the mediatorial role taken up by the figure of Isaiah 61 in relation to the preceding four servant songs. This means inter alia that the personality referred to in Isaiah 61 cannot simply be some figurehead, but an active role player, the servant of the Lord himself. He acts as transferor of privileges/benefits granted by the Lord to the advantage of his people. 


\section{Works consulted}

Alter, R \& Kermode, F (ed) 1989. The literary guide to the Bible. London: Fontana.

Baltzer, K 2001. Deutero-Isaiah: A commentary on Isaiah 40-55, tr by M Kohl. Minneapolis: Fortress Press. (Hermeneia.)

Beuken, W A M 1983. Jesaja, Deel II B. Nijkerk: Callenbach. (POT.)

Beuken, W A M 1989a. Jesaja, Deel III A. Nijkerk: Callenbach. (POT.)

Beuken, W A M 1989b. Servant and herald of good tidings: Isaiah 61 as an interpretation of Isaiah 40-55, in Vermeylen, J (ed), The book of Isaiah, 411-442. Leuven: Peeters. .BETL LXXXI

Blenkinsopp, J 1995. The "servants of the Lord" in third Isaiah: Profile of a pietistic group in the Persian epoch, in Gordon R P (ed), "The place is too small for us": The Israelite prophets in recent scholarship, 392-412. Winona Lake, Ind: Eisenbrauns.

Blocher, H 1975. Songs of the servant. London: Inter-Varsity Press.

Bratcher, R G 1984. The mission of the servant of the Lord: Luke 3:1-4:30. Faith and Mission 2(1), 65-71.

Brownlee, W H 1964. The meaning of the Qumran scrolls for the Bible with special attention to the book of Isaiah. New York: Oxford University Press.

Brueggemann, W 1998. Isaiah 40-66. Louisville, KT: Westminster John Knox. (Westminister Bible Companion.)

Cannon, W W 1929. Isaiah 61:1-3 an Ebed Yahweh poem. ZAW 47, 284-289.

Childs, B S 2001. Isaiah. Louisville, KT: Westminster John Knox.

Curtis, V S 1996. Persian myths: The legendary past. London: British Museum Press.

De Leeuw, V 1956. De Ebed Yahweh-profetieen: Historisch-kritisch onderzoek naar hun ontstaan en hun betekenis. Assen: Van Gorcum.

Delitzsch, F 1889. Biblical commentary on the prophecies of Isaiah, II. Edinburgh: T\&T Clark.

Dijkstra, M 1978. De koninklijke Knecht: Voorstelling en investituur van die Knecht des Heren in Jesaja 42, in Grosheide, H H (red), De Knecht: Studies rondom DeuteroJesaja, aangeboden aan J L Koole. Kampen: Kok.

Dillard, R B \& Longman III, 1994. An introduction to the Old Testament. Grand Rapids, Michigan: Zondervan. 
Dion, P E 1988. Institutional model and poetic creation: The first song of the servant of the Lord and appointment ceremonies, in Eslinger, L \& Taylor J G (eds), Ascribe to the Lord: Biblical and other studies in memory of P C Craigie, 319-339. Sheffield: Sheffield Academic Press. (JSOT 67.)

Du Plessis, I J 1995. Die Evangelie volgens Lukas, Deel I. Kaapstad: Lux Verbi.

Ekblad, R E 1999. Isaiah's servant poems according to the Septuagint: An exegetical and theological study. Leuven: Peeters.

Fiedler, P 1997. The servant of the Lord: Israel (Isa 42:1-6) and Jesus (Mat 12:18-21). Covenant Quarterly 55, 119-129.

Gileadi, A 1982. The apocalyptic book of Isaiah. New York: Hebraeus Press.

Gileadi, A 1988. The Davidic covenant: A theological basis for corporate protection, in Gileadi, A (ed), Israel's apostasy and restoration: Essays in honor of $R K$ Harrison. Grand Rapids, MI: Baker Book House, San Franciso.

Gileadi, A 1994. The literary message of Isaiah. New York: Hebraeus Press.

Goedicke, H (ed) 1971. Near Eastern Studies in honour of W F Albright. Baltimore: Johns Hopkins Press.

Goulder, M 2000. The Anointed, in Moyise, S (ed), The Old Testament in the New Testament: Essays in honour of J L North, 66-74. Sheffield: Sheffield Academic Press. (JSNT Supp series 189.)

Gordon, R P (ed) 1995. "The place is too small for us". The Israelite prophets in recent scholarship. Winona Lake, Ind: Eisenbrauns.

Grosheide, H H et al (red.) 1978a. De Knecht: Studies rondom Deutero-Jesaja. Aangeboden aan J L Koole. Kampen: Kok.

Grosheide, H H 1978b. De Knechtsgestalte van Christus: Aangeboden aan H N Ridderbos. Kampen: Kok.

Guthrie, D et al (eds) 1970. New Bible Commentary. Leicester: Inter-varsity Press.

Harrison, R K 1977. Introduction to the Old Testament. Grand Rapids, MI: Eerdmans.

Jenni, E \& Westermann, C (eds) 1975. Theologisches Handwörterbuch zum Alten Testament, Bd I. München: Kaiser Verlag. (THAT.)

Johnson, R F 1993. Christ the servant of the Lord, in Charlesworth, J (ed), The Old and New Testaments: Their relationship and the "intertestamental" literature, 107136. Valley Forge, PA: Trinity Press International. 
Kaiser, W C 1979. Toward an Old Testament theology. Grand Rapids, MI: Zondervan.

Kapelrud, A S 1971. The identity of the suffering servant, in Goedicke, H (ed), Near Eastern Studies in honour of W F Albright, 307-314. Baltimore: Johns Hopkins Press.

Kidner, D 1970 1978. Isaiah, Guthrie, D et al (eds), New Bible Commentary. Leicester: Inter-Varsity Press.

Korpel, M C A 1996. The female servant of the Lord in Isaiah 54, in Becking, B et al (eds), On reading prophetic texts: Gender-specific and related studies in memory of F van Dijk-Hemmes, 153-157. Leiden: E J Brill.

Koole, J L 1990. Jesaj,a II. Tweede druk. Kampen: Kok. (COT.)

Koole, J L. Jesaja, III. Kampen: Kok. (COT.)

Kruger, H A J 1984. Verbond en apokaliptiek in Jesaja 56 tot 66. Unpublished DTh thesis, University of Stellenbosch.

Kruger, H A J 1993. Infant negotiator? God's ironical strategy for peace: a perspective on child-figures in Isaiah 7-11, with special reference to the royal figure in Isaiah 9:5-6. Scriptura 44, 66-88.

Lisowski, G 1958. Konkordanz zum Hebräischen Alten Testament. Stuttgart: Württembergische Bibelanstalt.

Motyer, J A 1980. Messiah, in Douglas, J D et al (eds), The illustrated Bible dictionary, Vol II. Leicester: Inter-varsity Press.

North, C 1956. The suffering servant in Deutero-Isaiah: An historical and critical study. Oxford: Oxford University Press.

Odendaal, D H 1970. The eschatological expectation of Isaiah 40-66 with special reference to Israel and the nations. Nutley: Presb and Ref Publishing Co.

Odendaal, D H. Die Heilige van Israel in eskatologiese perspektief in Jesaja 40-66, in Verhoef, P A (red), Sol Iustitiae, 167-190. Kaapstad: NG Kerk Uitgewers.

Paul, S M 1968. Royal inscriptions. JAOS 88, 180-186.

Prinsloo, G T M 1999. Jesaja in Bybellennium, 769-836. Vereeniging: CUM.

Rogerson, J 1999. Chronicle of the Old Testament kings: The reign-by-reign record of the rulers of ancient Israel. London: Thames \& Hudson.

Sawyer J F A 1989. Daughter of Zion and servant of the Lord in Isaiah: A comparison. JSOT 44, 89-107. 
Schenker, A 1982. Nebukadnezzars Metamorphose vom Unterjocher zum Gottesknecht: In den beiden Jeremia-Rezensionen. Revue Biblique 89, 498-527.

Schökel, L A 1989. Isaiah, in Alter, R \& Kermode, F (ed), The literary guide to the Bible, 165-183. London: Fontana.

Smith, P A 1995. Rhetoric and redaction in Trito-Isaiah: The structure, growth and authorship of Isaiah 56-66. Leiden: Brill.

Soggin, J A 1975. מלך König, in Jenni E \& Westermann C (Hrsg), Theologisches Handwörterbuch zum Alten Testament, Bd I, 908-920. München: Kaiser Verlag. (THAT.)

Thomson, J G S S 1955. The shepherd-ruler concept in the Old Testament and its application in the New Testament. SJT 8, 406-418.

Van der Kooij, A 1997. The servant of the Lord: a particular group of Jews in Egypt according to the Old Greek of Isaiah: Some comments on the LXX Isa 49, 1-6 and related passages, in Van Ruiten J et al (eds), Studies in the book of Isaiah, 383396. Leuven: Peeters.

Van Ruiten, J \& Vervenne, M (reds) 1997. Studies in the book of Isaiah: Festschrift W A M Beuken. Leuven: Peeters.

Verhoef, P A (red). Sol Iustitiae. Cape Town: NG KerkUitgewers.

Vermeylen, J (ed) 1989. The book of Isaiah. Leuven: Peeters. BETL LXXXI.

Watts, J D W 1985. Isaiah 1-33. Waco, Texas: Word Books. (Word Biblical Commentary 24.)

Vosloo, W \& Van Rensburg, F J (reds) 1999. Die Bybellennium: Eenvolumekommentaar. Vereeniging: CUM.

Watts, J D W 1987. Isaiah 34-66. Waco, Texas: Word Books. (Word Biblical Commentary 25.)

Westermann, C 1967. Handbook to the Old Testament. Minneapolis, MS: Augsburg.

Wiesel, E 1970. A beggar in Jerusalem: A novel. London: Weidenfeld \& Nicholson.

Wilshire, L E 1975. Servant-city: A new interpretation of the servant of the Lord in the servant songs of Deutero-Isaiah. JBL 94, 356-367. 